\title{
OPEN The largest known cowrie and the iterative evolution of giant cypraeid gastropods
}

\author{
Stefano Dominici ${ }^{1 凶}$, Mariagabriella Fornasiero ${ }^{2}$ \& Luca Giusberti ${ }^{3}$
}

Based on the fossil record, we explore the macroevolutionary relationship between species richness and gigantism in cowries (Cypraeidae), the best-studied family of gastropods, with a global diversity distribution that parallels that of tropical corals, mangroves and seagrasses. We introduce Vicetia bizzottoi sp. nov. based on a Priabonian fossil found in northeastern Italy, the largest documented cowrie found so far and the youngest of a lineage of Eocene Gisortiinae species. The Gisortiinae stratigraphic record in western Europe indicates that species selection favoured large size and armouring of the shell. Palaeoecology and per-stage species richness suggest that gigantism occurred in peripheral habitats with respect to diversity hotspots, where smaller species were favoured. The Eocene-Oligocene boundary was marked by a turnover and the Chattian global warming favoured small-sized species of derived clades. Species selection leading to gigantism is further documented in Miocene lineages of Zoila and Umbilia, in the southern hemisphere, two extant genera distributed at the periphery of modern diversity hotspots, suggesting that the negative relationship between size and diversity is a recurring pattern in the evolutionary history of cowries. This palaeontological evidence is projected onto the existing hypotheses that explain analogous biogeographic patterns in various other taxa. Likewise, body size-species richness negative relationship was possibly driven in cowries by physiological, ecological and life history constraints.

Covariance between community species richness and body size of resident species have been studied in a variety of marine invertebrates, suggesting different relationships of these two important ecological traits. While diversity generally decreases with latitude and depth ${ }^{1,2}$, in many ectotherms body size increases, although not all ${ }^{3-6}$. Clues among the Cypraeidae (cowries), the best-studied gastropods ${ }^{7}$, suggest that where diversity is highest species tend to be smaller. The hotspot of cypraeid diversity, for example, centred in the Indo-West Pacific (IWP ${ }^{1,8}$ ), does not yield the largest species, living instead in the Carribean Sea (Macrocypraea cervus, up to $190 \mathrm{~mm})^{7}$. Large and very large cowries occupy deep habitats in western and southern coasts of Australia, on the opposite side of a sharp diversity cline that peaks in the Philippines, where up to more two hundred species of smaller forms live amidst a variety of reef organisms ${ }^{8}$. These are neighbouring, more than phylogenetically related ${ }^{8-10}$, with clades like the small-sized Erosariinae and Erroneinae experiencing the highest diversity ${ }^{11}$. The negative relationship among these ecological traits suggests either that an inherited propensity to gigantism was shared by some clade, but not by those that radiated at the tropics, or that the trait is controlled by ecological factors that favour relict clades of peripheral habitats, at higher latitudes or deeper and cooler waters with respect to centres of diversity ${ }^{2}$. The discovery of a $335 \mathrm{~mm}$-long fossil of the largest cowrie ever to be documented, belonging to a new species of extinct genus Vicetia, extends our knowledge of gigantism in cowries of subfamily Gisortiinae. Recent taxonomic revisions of the European fossil record allow to frame this finding within the wider context of cypraeid diversity, shedding light on the nature of macroevolutionary pathways that led to a striking example of gigantism. The aim of this paper is to describe the new species and present a synthesis of the Eocene-Miocene distribution of European cowries, focusing on species richness and maximum reported size of each species, to test the consistency of an hypothesis of negative relationship between gigantism and diversity in this particular molluscan clade. The fossil record is then confronted with modern macroecological theory to explore what physiological, ecological and life history constraints regulated the evolution of gigantism among cowries.

\footnotetext{
${ }^{1}$ Museo di Storia Naturale, Università degli Studi di Firenze, Florence, Italy. ${ }^{2}$ Museo di Geologia e Paleontologia, Università degli Studi di Padova, Padua, Italy. ${ }^{3}$ Dipartimento di Geoscienze, Università degli Studi di Padova, Padua, Italy. ${ }^{\circledR}$ email: stefano.dominici@unifi.it
} 
Geology and age. The large specimen of Vicetia bizzottoi sp. nov. was found in the upper part of the Possagno Marl Formation near the Cunial quarry, Possagno (Treviso province, Veneto region of NE Italy). Gently dipping towards SSE, this unit is part of the monocline dividing the Mesozoic succession of the Monte Grappa massif, in the southeastern Alps, from the Venetian Plain. The sedimentary Priabonian succession cropping out at Possagno, about $45 \mathrm{~km}$ to the NW of Priabona, is the thickest expression of this time interval in the region and thus formerly proposed as parastratotype section of the Priabonian stage (upper Eocene ${ }^{12}$ ). During this interval Veneto formed part of a vast embayment in the western sector of the Tethys Sea, delimited to $\mathrm{N}$ and $\mathrm{E}$ by the European continent and to W and S by the early expression of the Apennine chain (Fig. 1a). The fossil was collected in grey mudstone, part of a coarsening-upward alternation of shelly mudstones with thinner sandstone intervals, about $30 \mathrm{~m}$ below the base of the overlying Pradelgiglio Limestone Formation ${ }^{13}$ (Fig. 1b,c). A skull of the sirenian Prototherium intermedium (specimen $\mathrm{B}^{14}$ ) was found in the same interval, together with bivalves Pycnodonte gigantica, Chama granulosa and Crassatella sp., gastropods Ampullinopsis crassatina and Clavilithes yapeti and solitary corals Pattalophyllia subinflata, P. roseni, Placosmiliopsis fimbriatus, Wellsotrochus polygonata and Montanarophyllia exarata ${ }^{15}$. The microfaunal assemblage includes fragments of regular echinoids and nummulitid and large miliolid foraminifera, suggesting depth within the photic zone, while the coral and otolith assemblages indicate an offshore shelf palaeoenvironment ${ }^{16,17}$.

\section{Results}

Systematic palaeontology. Class Gastropoda Cuvier, 1797.

Order Littorinimorpha Golikov and Starobogatov, 1975.

Family Cypraeidae Rafinesque, 1815.

Subfamily Gisortiinae Schilder, 1927.

Genus Vicetia Fabiani, 1905.

Type species Ovula hantkeni Lefèvre T., 1878; Monte Postale (Bolca), Italy; lower Eocene, upper Ypresian.

Referred species The type species, Vicetia bellardii (Deshayes in Bellardi, 1852); Palarea (Blausasc), France; middle Eocene, Bartonian; Vicetia gennevauxi (Doncieux, 1908); Coustouge (Corbières), France; lower Eocene, Ypresian; Vicetia jamesi (Vredenburg, 1927); Sind, Pakistan; middle Eocene; Vicetia bizzottoi sp. nov. Possagno, Italy; upper Eocene, middle Priabonian.

Original diagnosis Subcypraeiform, bulky, smooth, completely involuted shell; two bulgy transversal dorsal ridges; wide and slightly convex ventral side; long aperture, cut at the two extremities; denticulations on outer lip; anterior columellar fold with some denticulations ${ }^{18}$.

Remarks Vicetia has been considered synonym ${ }^{19}$ or subgenus ${ }^{20}$ of Gisortia, Jousseaume, 1884, type species Cypraea coombii J. de C. Sowerby, 1850. The general shape (barrel-like vs oval), the number of transversal dorsal ridges (two or one) and the shape of the aperture (sinuous and narrow vs more straight and opening anteriorly), allow to clearly separate two clades that deserve the status of separate genera, as recognised by recent literature ${ }^{21}$.

Vicetia bizzottoi sp. nov.

LSID urn:Isid:zoobank.org:act: BD76B5C2-3B4B-4D5E-8EC7-A6A2779F65DE.

Etymology Patronymic. The new species is dedicated to Mr. Bruno Bizzotto, discoverer and preparator of the type specimen.

Holotype MGP-PD 32314 (holotype by monotypy: Fig. 2).

Material The holotype MGP-PD 32314, housed in the Museo di Geologia e Paleontologia of the Padova University, Italy.

Locality and horizon. Only known from the vicinity of Cunial quarry fossil site, in Possagno, Treviso, in northeastern Italy, Possagno Marl Formation (middle-upper Priabonian, upper Eocene ${ }^{22,23}$ ).

Diagnosis. Two acute dorsal ridges that converge dorsally in the midline; two very long and pointed protuberances originating from the ventral side and extending to the left, curved towards the dorsal side; a twisted and adapically-protruding exhaling canal.

Differential diagnosis. The two acute dorsal ridges and the narrow and long aperture are consistent with the diagnosis of Vicetia and the referred specimen is here regarded as pertaining to a new species.

The type species of Vicetia, V. hantkeni, is well-known in the lower and middle Eocene of western Europe (Ypresian of Veneto and Friuli, Italy; Lutetian of France), also under the junior synonyms Vicetia o'gormani Cossmann, $1923^{24}$ and Vicetia douvillei Cossmann and Pissarro, $1911^{21}$. It differs for its much smaller size and the blunt dorsal ridges, more distant from one another than in Vicetia bizzottoi sp. nov. It lacks a protruding exhaling canal and has only one blunt and much shorter lateral protuberance.

Vicetia gennevauxi (Doncieux, 1908) is known only from the lower Eocene of the French Pyrenees (Ypresian of the Corbières, France). This is the smallest and less ornamented of all species of the group, assigned to the same genus for its two faint dorsal ridges.

The closest species is the middle Eocene Vicetia bellardii (Deshayes in Bellardi, 1952), found in the Lutetian of the Paris Basin and Bartonian of North (Val d'Oise) and South France (Alpes-Maritimes) and in the southern Pyrenees, in Spain, under the junior synonyms Ovula gigantea hoernesi Lefèvre, 1878, and Gisortia vicetiana (Farrés and Stadt 2009) ${ }^{21}$. Adult specimens are from large to very large (up to $280 \mathrm{~mm}$ ), not attaining the size of Vicetia bizzottoi sp. nov. The two dorsal ridges are blunt and equidistant. Lateral protuberances are two and sharp, but very short and not pointed. The aperture is slightly wider and gently curved, not sinuous. Bartonian specimens from the Spanish Pyrenees have a long, but untwisted exhaling canal (or tubular anterior channel $^{24}$ ). 

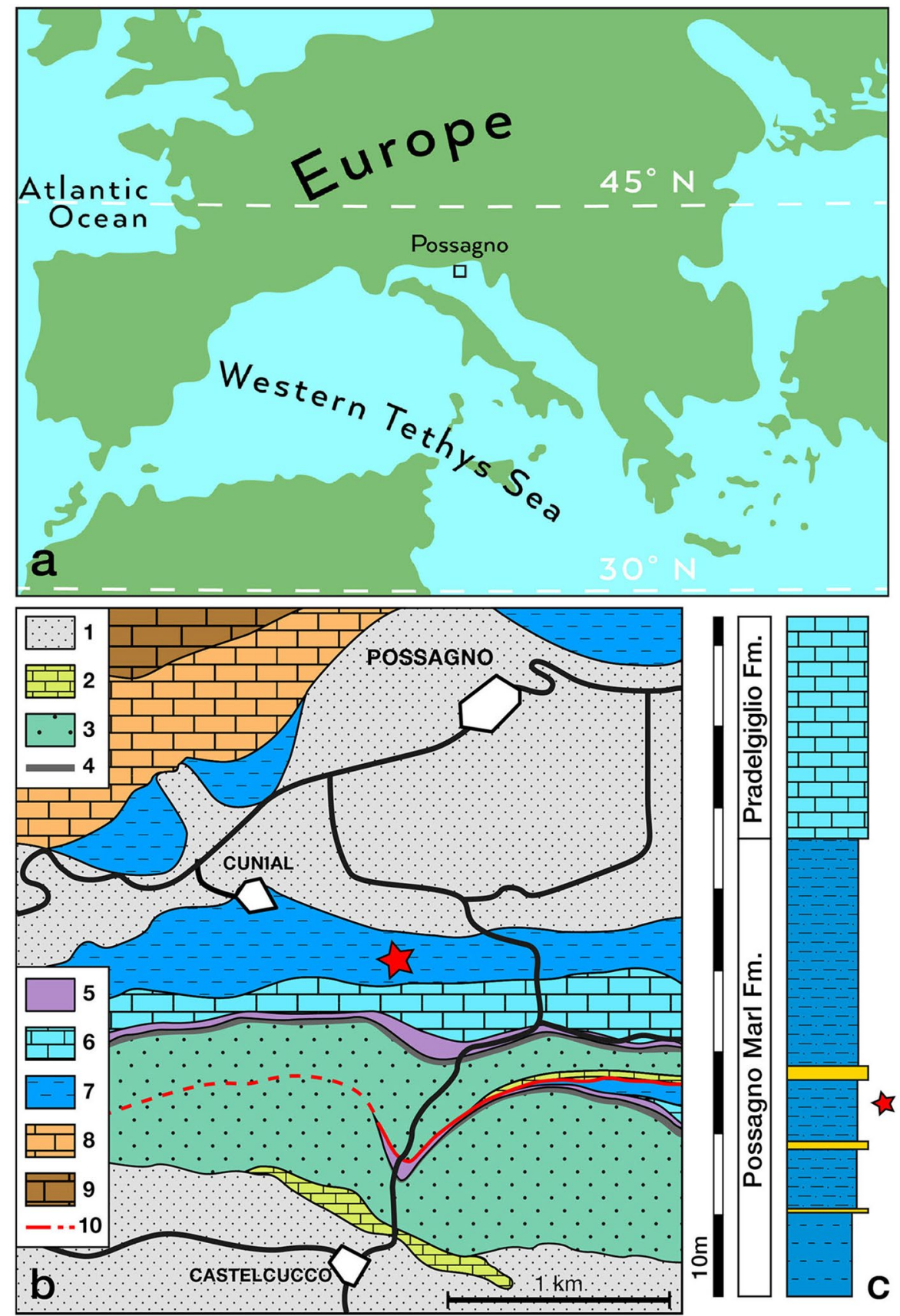

Figure 1. Location and geology of the Possagno area (northeastern Italy) and Vicetia bizzottoi fossil site. (a) Palaeogeography of western Europe with location of the study area. (b) Simplified geological map of the Possagno area with position of the Vicetia bizzottoi sp. nov. fossil site (red star). 1: Quaternary deposits; 2: Castelcucco calcarenite (Miocene); 3: glauconitic calcarenite (Miocene); 4: conglomerates (upper Oligocenelower Miocene); 5: upper Possagno Marl Formation (upper Eocene); 6: Pradelgiglio Formation (upper Eocene); 7: Possagno Marl Formation (upper Eocene); 8: Scaglia Cinerea (middle-upper Eocene); 9: Scaglia Rossa (Upper Cretaceous-lower Eocene); 10: fault ${ }^{75}$. (c) Simplified stratigraphic log with position of the Vicetia bizzottoi sp. nov. bed (red star). Symbols for the Possagno Marl Fm. indicate marls and silty marls, in blue, and fine-grained sandstones, in orange. Maps created with Adobe Illustrator CC 2017 (21.0; https://helpx.adobe.com/it/illustrato r/release-note/illustrator-cc-2017-21-0-release-notes.html).

Description. Gigantic cowrie, twice the average size of species of the same subfamily (based on length: Supplementary Table SI2); the posterior size of the shell is larger than the anterior; the aperture is narrow, sinuous and very long, with two convexities facing to the right; the exhaling canal is twisted and protruded, about one 


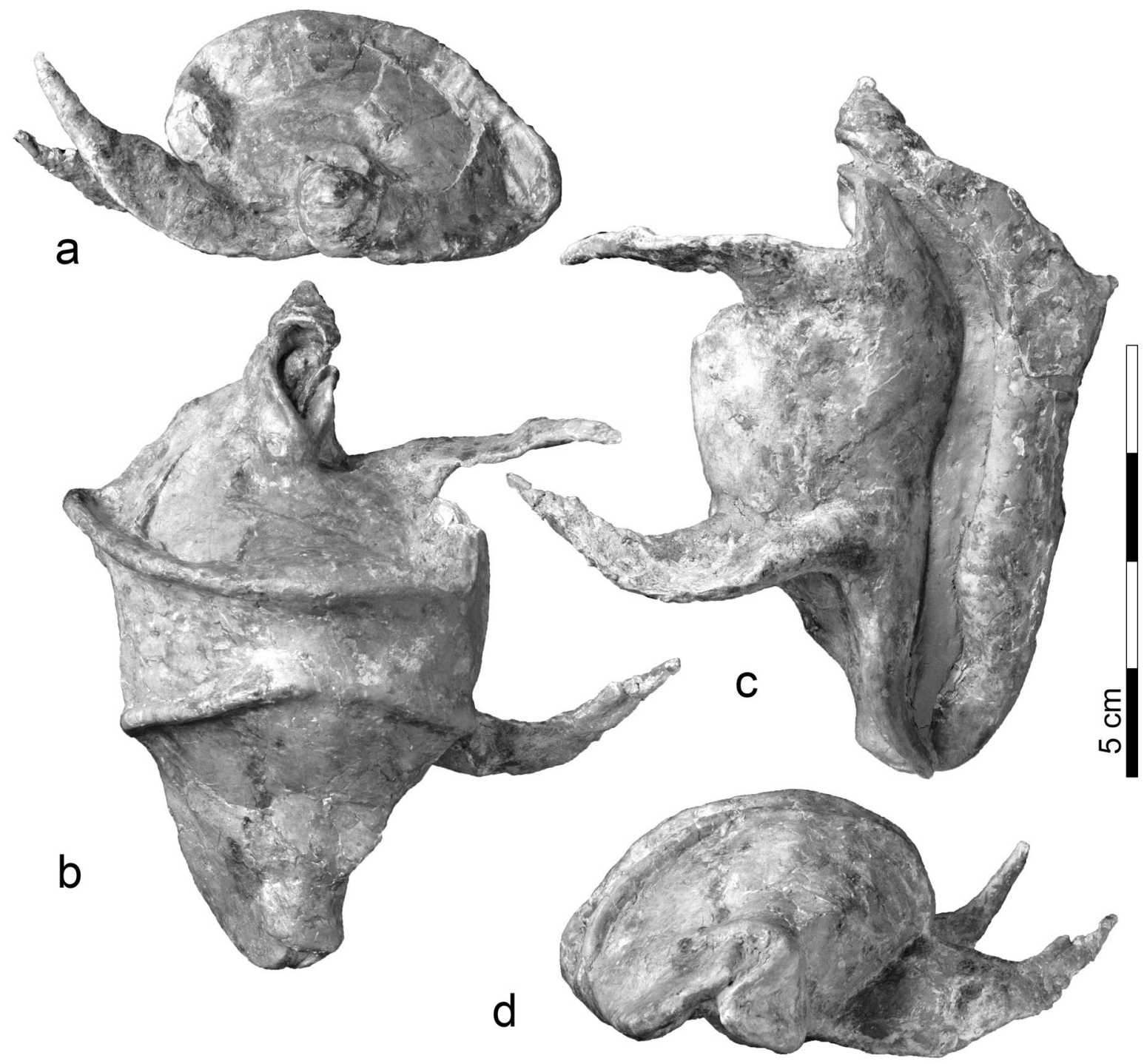

Figure 2. Shell of Vicetia bizzottoi sp. nov. (Holotype MGP-PD 32314). (a) Posterior view, (b) ventral view, (c) dorsal view, (d) anterior view.

fifth of the whole shell length, slightly pointing to the left; the dorsal side is crossed by two acute ridges, coming closer towards the midline and distancing both to the left and the right side; on the right side of the shell the posterior ridge is more pronounced than the anterior, merging with the outer lip at about one third of its length; on the left side the two ridges are less pronounced and rapidly disappear ventrally. Two very long and pointed protuberances protrude from the ventral side of the shell; the anterior one merges with the inner lip at about two fifths of its length; the posterior protuberance disappears ventrally and anteriorly, but connects posteriorly with the anterior flank of the exhaling canal; the two protuberances are about as long as the body of the width of the shell at the point of junction; they arch dorsally and end with sharp points. Apart from the dorsally sharp ridges and protuberances, the surface of the shell is smooth.

\section{Discussion}

Stratigraphic distribution. The fossil record of Vicetia in western Europe (England, France, Spain and Italy) has been recently reviewed ${ }^{19,21,24}$, resulting in the recognition of three species of late Ypresian-Bartonian age (early-middle Eocene), other names being placed in synonymy. A fourth species described here positively extends the record of the genus to the Priabonian (upper Eocene), so far known only from moulds of doubtful attribution (specimens from Lonigo and Brendola, two Priabonian localities not far from Possagno ${ }^{22}$ ). The stratigraphic range of the first three species partly overlaps (Fig. 3), but a distinct stratigraphic trend is detected (Fig. 4a), from the Ypresian relatively small-sized Vicetia gennevauxi, with no pronounced ornaments, to the Ypresian-Lutetian medium-sized Vicetia hantkeni, with blunt ornamentation and one lateral projection, to the middle Eocene large to gigantic Vicetia bellardii with blunt ornamentation and two projections, to the gigantic upper Eocene Vicetia bizzottoi sp. nov., with sharp and long ornaments. A parallel trend is seen in two species of the other gigantic genus Gisortia of western Europe. Gisortia tuberculata is mainly found in upper Ypresian 


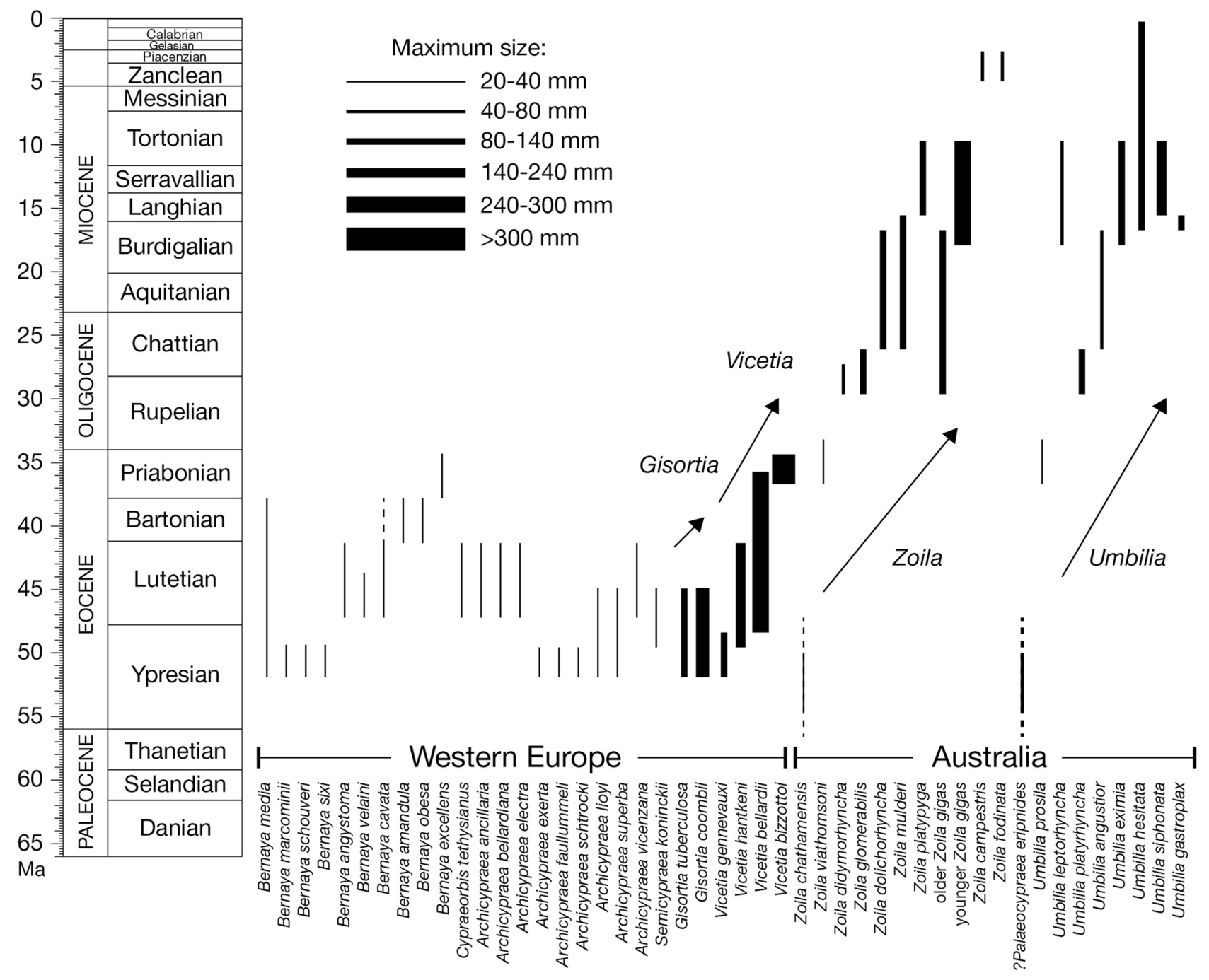

Figure 3. Stratigraphic range of Gisortiinae cypraeids in western Europe and genera Zoila and Umbilia in Australia. Maximum known shell size shown by line thickness. Arrows indicate trends in size increase recognised in successive species of four distinct genera.

beds of France and only rarely in lower Lutetian glauconitic beds of southern England ${ }^{25,26}$, whereas Gisortia coombii, present in the same beds and same localities, becomes distinctly more abundant and widespread in the Lutetian $^{25}$. The two species have different size and ornamentation ${ }^{25,26}$, showing a tendency parallel and partly contemporaneous to species of Vicetia (Fig. 4b). Other genera of subfamily Gisortiinae, widespread in several basins of northwestern Atlantic and western Tethys ${ }^{27}$, are more diversified (Bernaya, Archicypraea), smaller than Vicetia and Gisortia, showing no increase in size in time (Fig. 3).

A second group of very large and gigantic fossil cowries is found in the Neogene of the southern hemisphere belonging to Zoila and Umbilia ${ }^{28,29}$. The stratigraphic distribution of the several species of these two genera shows net increase in size. From small early Eocene ancestors, successive Zoila species become larger during the Oligocene and early Miocene, until reaching the maximum size in the middle Miocene with Zoila gigas (Fig. 4c). A parallel trend is seen in Umbilia, attaining very large size and long siphons with Umbilia siphonata, passing through species of intermediate size (Fig. $4 \mathrm{~d})$.

Habitats. Habitats and niches occupied by basal Gisortiinae Gisortia and Vicetia can be indirectly reconstructed from synecological and palaeonvironmental context and from functional morphology. Gisortia coombii and G. tuberculata, in association with large strombid Hippocrenes amplus and bivalves Venericor plancosta and Venericardia acuticosta ${ }^{30}$, are mainly known from the lower Lutetian Earnley Formation ${ }^{25}$, a glauconitic sandstone unit of the Braklesham Group (Sussex, England) deposited in a sediment-starved offshore setting ${ }^{31-33}$. A similar association is found in the lower Lutetian at Gisors, in the Paris Basin (France), where Gisortia coombii is associated with Hippocrenes amplus ${ }^{34}$ in the Nummulites laevigatus limestone, interpreted as a lower-shoreface deposit $^{35}$. The same species is associated with Sycostoma pyrenaica and species of Strepsidura and Volutilithes in open-marine silty sandstones of the Esera valley (Aragon, Spain ${ }^{36}$ ), part of an oligotrophic ramp association ${ }^{37}$. A similar association is recognised in the Lutetian of Vic area (Catalonia, Spain), where G. coombii is associ- 


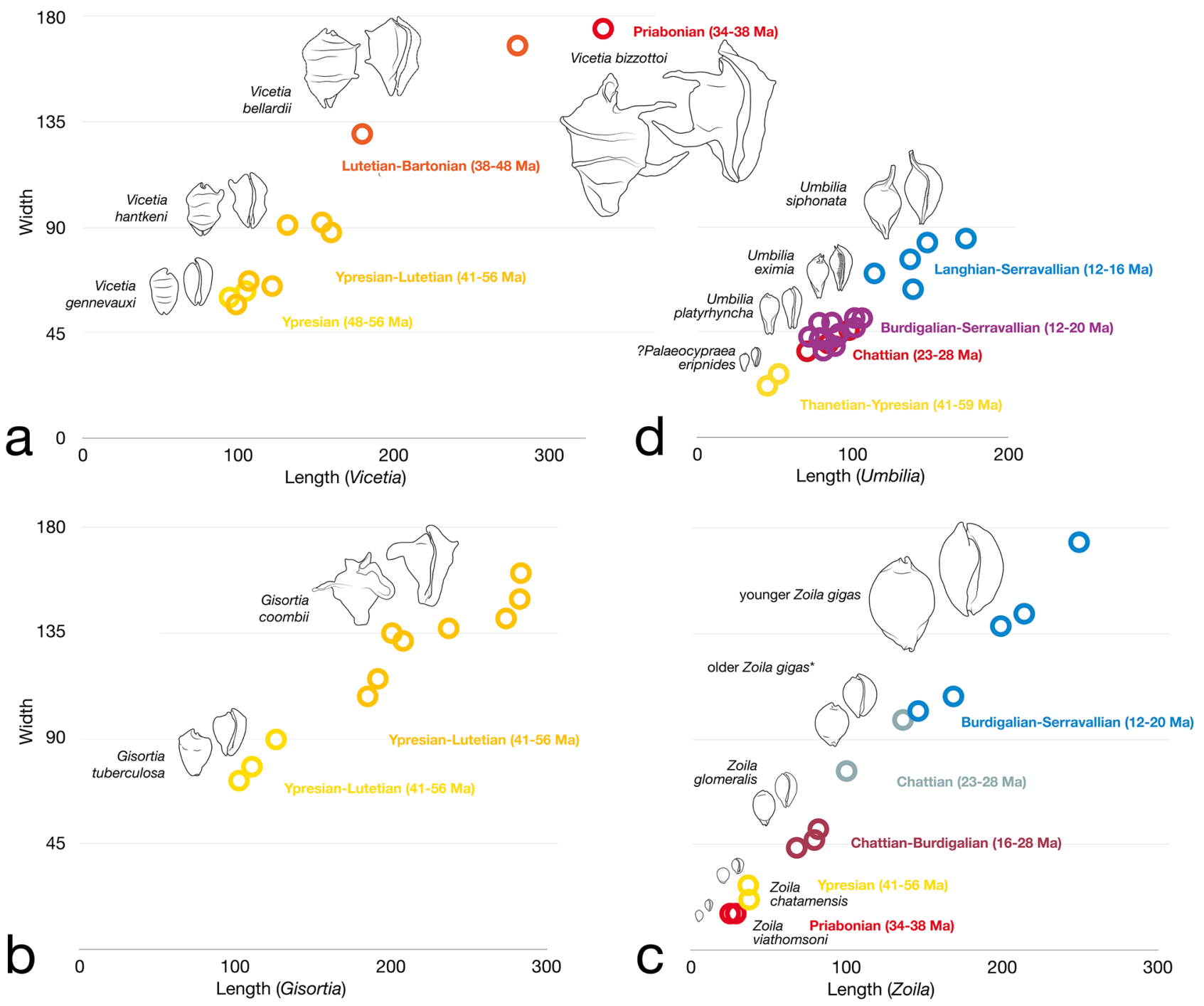

Figure 4. Lineages of cowries from the Eocene of western Europe (a,b) and the Cenozoic of Australia (c,d). (a) Four successive species of Vicetia show increase in size and armouring. (b) Two contemporaneous species of Gisortia have different size range and armouring. (c) Four species of the lineage that leads to middle Miocene Zoila gigas. ${ }^{\star}$ Chattian specimens, of smaller size and shorter canals, were previously attributed to different species (Supplementary Information SI1). (d) Species chosen to show net size increase the connects the small Palaeocypraea? eripnides to the middle Miocene Umbilia siphonata.

ated with large gastropods (Campanile, Velates, strombids) and shark teeth ${ }^{38}$. Vicetia hantkeni occurs in upper Ypresian shelly Alveolina limestones at Monte Postale (Veneto, Italy), within a high-diversity association that includes abundant Archicypraea lioyi and herbivores (Cerithium chaperi, Pseudobellardia gomphoceras ${ }^{39}$ ). The Monte Postale Alveolina limestone is interpreted as part of a complex coralgal setting ${ }^{40,41}$. Vicetia cf. hantkeni occurs in association with abundant Nummulites and other large molluscs in the upper Ypresian of the Esera valley, in open shelf marls ${ }^{37}$. Very large specimens of Vicetia bellardii are recovered in Bartonian marls of the Vic area (Catalonia) in association with large gastropods (Campanile, Velates) and deeper subtidal forms such as Discocyclina, bryozoans and arbacid echinoderms ${ }^{38}$. At the antipodes with respect to western Europe, Australian fossil gisortiinae are mainly known from the Serravallian Muddy Creek Marl Member of the Port Campbell Limestone (Otway Basin, Victoria). This unit is associated with a well-diversified molluscan fauna ${ }^{42}$, including neogastropods Serratifusus craspedotus and Hispidofusus senticosus ${ }^{43}$ and abundant cetacean and shark remains $^{44}$, overall indicating a starved offshore shelf setting. In conclusion, larger gisortine cowries have always preferred offshore-lower shoreface depths in sediment-starved shelves, in association with herbivore and carnivore gastropods, phototrophic larger foraminifera and azooxanthellate solitary corals. If we assign to past cowries the same diet of modern descendants, then Vicetia and Gisortia, like Zoila ${ }^{45}$, ate sponges preferably at 30-50 $\mathrm{m} \mathrm{depth}^{46}$, competing for the same prey with other gastropods (e.g., Columbellidae $\mathrm{e}^{47}$ ). If relying on algae, then they possibly competed with strombids and other very large gastropods. This description fits high levels of competition in a low productivity, high-diversity stable ecosystem. The role played by gisortine cowries was that of low-metabolism, vagile predators adapted to feed on an energy-poor sessile animal resource, eventually 
switching to even poorer vegetal substitutes. Much unlike the average predator, large size and ornamentation were adaptations for defence of a 'gentle giant's .

Modern cowries are successful predators of tropical seas where they prefer hard bottoms, extending their geographic distribution to temperate seas, where they gradually diminish in diversity and abundance ${ }^{7}$. Diversity trend parallels those of fishes and other predators, reflecting patterns of habitat-structuring organisms such as corals, mangroves and seagrasses ${ }^{1}$. In tropical habitats, small size of many cowrie species favours hiding during the day, moving and going out for prey only during the night. Favourite preys are sponges, hydroids, carrion, or algae $^{46-48}$. All cypraeids undergo larval development, except Zoila, Umbilia and Barycypraea that develop without any pelagic phase. These three genera occupy marginal habitats with respect to IWP hotspot of diversity, the first two living subtidally up to $300 \mathrm{~m}$-depth in temperate waters ${ }^{45,46,49,50}$, Barycypraea feeding intertidally during the day ${ }^{45,51}$. The three genera with a peripheral geographic distribution share basal positions in molecular phylogenies ${ }^{9,10}$, suggesting a phylogenetic relationship with basal gisortiinae like those found in Europe. Furthermore, living Zoila and Umbilia occupy offshore habitats similarly to Gisortia and Vicetia and direct development has been hypothesised for the two extinct European giants ${ }^{42}$.

Macroevolution and biogeography. After the early Eocene climatic optimum, global temperature steadily decreased, until dropping at the end of the Priabonian ${ }^{52}$. Being unlikely that late-middle Eocene and late Eocene gigantic forms of France, Spain and Italy had migrated from the East, successive species of the same genus must have been connected by evolutionary relationships. The size increase seen in successive species of Vicetia (Fig. 4a) is thus an example of 'differential success of species' ${ }^{53}$, or species selection ${ }^{54}$, reflecting the progressive and net macroevolutionary change in one lineage from large and un-ornamented cowries, to gigantic and sharply rostrate forms. We hypothesise that species of Vicetia were direct developers, like extant Zoila, Umbilia and Barycypraea, founder speciation promoting high speciation rate ${ }^{8,55}$. This line of descent is a candidate example of heterochrony through peramorphosis, or increased morphological development during ontogen ${ }^{56}$, taking place by increase in growth rate of successive species and the progressively-earlier onset in the development of projections and ridges. The two species of Gisortia that co-occur with older species of Vicetia also suggest selection favouring larger species (Fig. 4b). The co-occurrence of up to four large or very large gisortiinae cowries during the Ypresian-early Lutetian, coupled to the high diversity of other genera of the same clade Gisortiinae, like Bernaya and Archicyprea (Fig. 3), is consistent with the hypothesis that the diversity hotspot at that time was centred in western Tethys ${ }^{57-59}$. Smaller species, associated with phototrophic corals and alveolinids (Archycypraea lioyi at Monte Postale ${ }^{39,40}$ ), decreased in diversity during the late-middle Eocene (Supplementary Fig. SI3). Offshore settings formed a refuge for larger remnants of the basal gisortines, as continental collision at $43 \mathrm{Ma}$ and closure of northern seaways ${ }^{60}$ hindered biotic exchange with the IWP. Climatic cooling and the onset of the Antarctic ice sheet at the Eocene-Oligocene boundary ${ }^{52}$ coincides with a turnover at the level of subfamilies. In western Europe only two species of Gisortiinae are known, the clade still hosting the larger forms, while small and very small cowries sharply increase in species richness. The Oligocene diversity increase, a global phenomenon ${ }^{25}$, occurs in two steps. Basal forms (Erosariinae, genus Proadusta) are particularly diversified in the Rupelian $\left(\mathrm{S}_{\text {total }}=24\right)$, derived subfamilies Luriinae, Pustulariinae and Erroneinae in the Chattian, as global temperature rises $^{52}\left(\mathrm{~S}_{\text {total }}=57\right.$ : Fig. 5, Supplementary Figs. SI3-SI4). Evolutionary success of Oligocene cowries is measured by high species richness and by the highest percent of species with sizes not exceeding $20 \mathrm{~mm}$ (Fig. 5; Supplementary Fig. SI3). Cypraeids continued to be well-diversified during the warmer early Miocene, after which western Europe finally became disconnected ${ }^{61}$ from the IWP diversity hotspot $^{57}$. As global climate progressively cooled ${ }^{52}$, middle and upper Miocene cowries decreased in richness (Supplementary Fig. SI3). Meanwhile at the other side of the globe, close to the new hotspot, a second rise to gigantism is observed in a clade reminiscing ancient Gisortiinae and including modern species of Zoila and Barycypraea. Both genera are direct developers that nest in molecular phylogenies ${ }^{10}$, one endemic to Australia ${ }^{28,45}$, the other surviving with two species in the western Indian Ocean ${ }^{11}$. Miocene species of Barycypraea show dorsal ornaments and a general shell-shape that suggests close phylogenetic relationships with Gisortiinae such as Vicetia hantkeni. They are particularly diversified in Java where they reach sizes of $60 \mathrm{~mm}$. It is however the fossil record of Zoila that shows a pattern analogous to the Vicetia predecessor, consistent with a hypothesis of random speciation and channelling by differential success towards gigantic size (Fig. 4c). A fourth case concerns species of genus Umbilia, forming a lineage that leads not just to very large size, but also to the progressive elongation of the anterior canal (Fig. 4d) and the eventual widening of the peripheral region in the flanged cowrie, Umbilia gastroplax ${ }^{29}$. The dramatic global increase of productivity in coastal waters that occurred during the Cenozoic, greatly differentiates tropical habitats between the Eocene and the Miocene, favouring the ecological success of gigantic predators ${ }^{62}$. The similarities between Eocene and Miocene patterns leading to gigantism among cowries (Fig. 4) suggest phylogenetic constraints that control maximum body size and shell ornamentation, where climate change and plate tectonics preside over what traits are preferentially selected.

Macroecology. Within-lineage body size increase over geologic time can be an effect of global cooling, as the macroevolutionary expression of the tendency for organisms to be larger in colder habitats ${ }^{63,64}$. The positive correlation between size and latitude, known as the temperature-size rule (TSR), is demonstrated for a large number of monophyletic clades of ectotherms ${ }^{65,66}$. This is not universal among benthic molluscs ${ }^{6,67}$, nor among all aquatic animals ${ }^{68}$, but recurring patterns in the cypraeid fossil record suggest that general causal TSR theories can be applied to the group, supported by experimental evidence on extant members of the family. By analogy with other modern lineages of ectotherms adapted to cold waters ${ }^{4}$, across-species body-size response of cypraeids was likely driven by selection acting on (1) physiological, (2) ecological, and (3) life history traits. (1) High ratio of oxygen availability at cold temperatures increases the window of body sizes into which lineages 


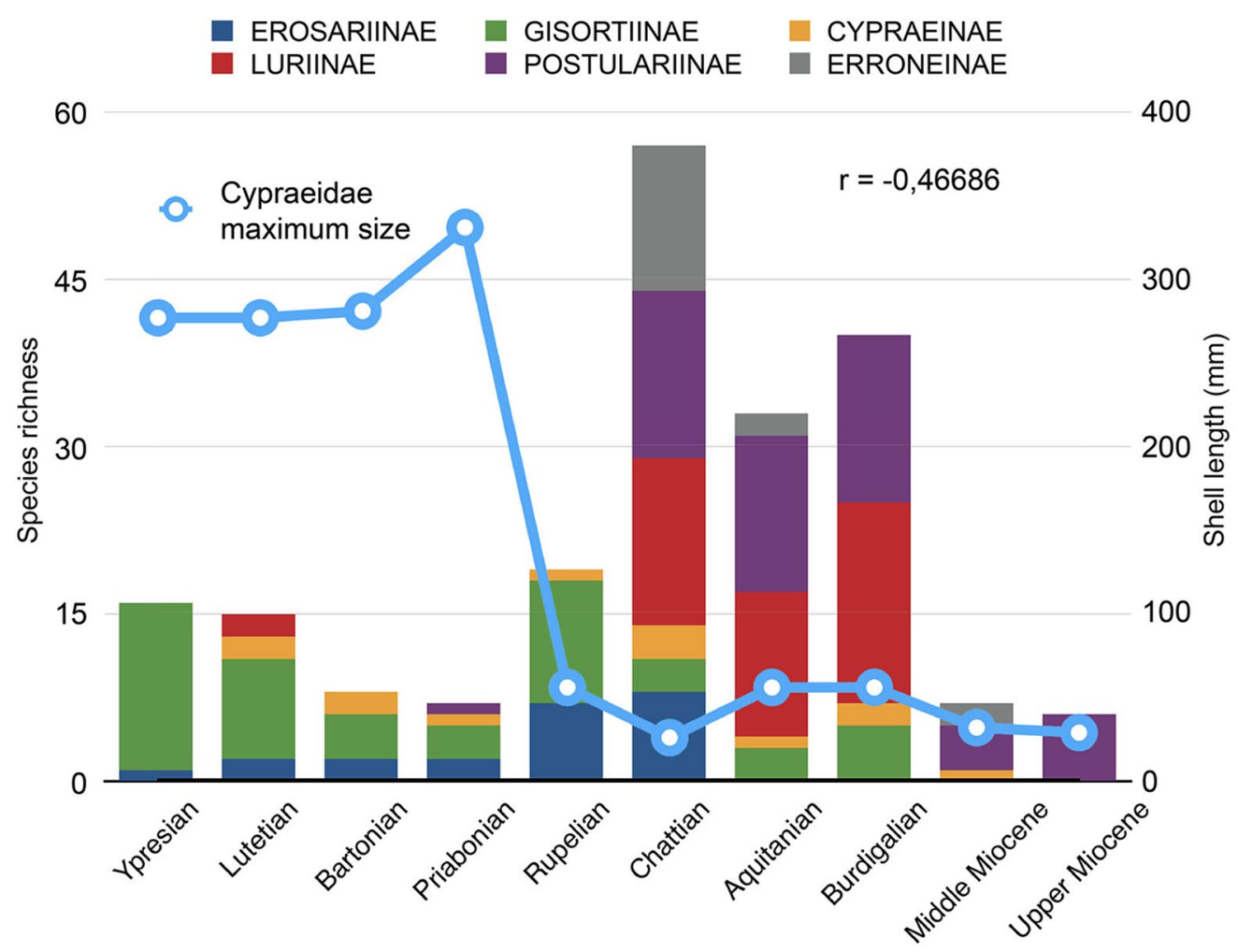

Figure 5. Species richness of western European cypraeid subfamilies during the Eocene-Miocene, compared to per-stage individual maximum size recorded in the family. The two values show a strong negative relationship (linear $\mathrm{r}=-0.46686$ ), particularly for the Eocene-middle Miocene, before the closure with connections with IWP (linear $r=-0.83099$ ).

diversify and is suspected to be a general driving force of the TSR ${ }^{66,69}$. (2) Energetics of foraging behaviour-a largely-unexplored field in cowries-could also explain selection for larger body size ${ }^{70}$, with smaller cowries tending to graze sessile organisms like sponges, and larger ones accessing mobile prey. Getting bigger would be advantageous for catching escapers. Selection for starvation resistance, stronger in cold climates, also favours large size $^{66}$. (3) The phenotypic plasticity in which ectotherms grow slower, but mature at a larger body size in colder environments, confirmed in cowries by laboratory rearing experiments ${ }^{71}$ and field surveys ${ }^{72}$, could be one driving force behind selection of larger forms during climatic cooling, at higher latitudes or in deeper waters. As an additional life history constraint, hatching at bigger would maximise fitness and be very important to getting a giant, shortening the period of growth. Bigger mothers would in their turn be advantageous for producing bigger eggs.

\section{Conclusions}

The discovery of the gigantic cowrie Vicetia bizzottoi sp. nov. in Priabonian offshore deposits of western Tethys widens our understanding of factors that drove a lineage of Eocene Cypraeidae towards gigantism. Cowries have an excellent fossil record, a proxy useful to trace and interpret Cenozoic diversity hotspots. The well-known European record of subfamily Gisortiinae allows to reconstruct macroevolutionary patterns that characterise successive Vicetia species and contemporaneous species of sister genus Gisortia. Four Eocene species of Vicetia have a distribution consistent with an hypothesis of species selection leading to gigantism and increased ornamentation. Species of Gisortia experienced an analogous ecological success during the first part of the Eocene, before western Tethys became disconnected by plate tectonics from the Indian Ocean. Cypraeid diversity decreased both locally and globally, before a turnover at the Eocene-Oligocene transition replaced basal cowries with derived forms. Derived clades became highly diversified during the Oligocene, but mostly through small and very small species, both in basal and derived clades. New episodes of differential species selection towards gigantic size are documented by the Australian record of late Oligocene-middle Miocene genera Zoila and Umbilia. Analogies with Eocene gisortiines include offshore soft-bottom habitat and marginal position with respect to contemporaneous centres of diversity, where small cowries experienced very high species richness in communities from hard substrata. A conservative hypothesis is that the documented cases reflect convergent evolution in unrelated Palaeogene (Gisortia and Vicetia) and Neogene lineages (Zoila and Umbilia), favoured by direct development and high speciation rates. This iterative pattern characterised cypraeid giants notwithstanding the Eocene and Miocene experienced different regimes of productivity. The fossil record suggests that gigantism is confined within Eocene Gisortiinae of western Tethys and modern IWP relict and peripheral clades, possibly belonging to the same lineage. Palaeontological patterns conform to a general theory of temperature-size rule, where the 
rise of giants among cowries is driven by the interplay of factors that pertain to their physiology, ecology, and life history traits, shaped on a macroevolutionary scale by climate change and plate tectonics.

\section{Methods}

The studied specimen was dug up and prepared using the usual palaeontological techniques. Species distributions and per-species maximum sizes were taken from updated palaeontological literature. Taxonomy follows the World Register of Marine Species ${ }^{73}$. Species richness was computed by artificially extending the stratigraphic range to the stage where each fossil was found and by including intervening stages in the case of discontinuous distributions. Correlation between per-stage species richness and maximum shell length was measured by linear $\mathrm{r}$ (Pearson's coefficient) using the software PAST $^{74}$.

Nomenclatural acts. The electronic edition of this article conforms to the requirements of the amended International Code of Zoological Nomenclature, and hence the new names contained herein are available under that Code from the electronic edition of this article. This published work and the nomenclatural acts it contains have been registered in ZooBank, the online registration system for the ICZN. The ZooBank LSIDs (Life Science Identifiers) can be resolved and the associated information viewed through any standard web browser by appending the LSID to the prefix "http://zoobank.org/". The LSID for this publication is: urn:lsid:zoobank. org:pub: BF3A9140-BDBB-4074-B3C7-39616E533574.

\section{Data availability}

All data generated or analysed during this study are included in this published article and its supplementary information files.

Received: 29 July 2020; Accepted: 27 November 2020

Published online: 14 December 2020

\section{References}

1. Sanciangco, J. C., Carpenter, K. E., Etnoyer, P. J. \& Moretzsohn, F. Habitat availability and heterogeneity and the Indo-Pacific warm pool as predictors of marine species richness in the tropical Indo-Pacific. PLoS ONE 8, e56245 (2013).

2. Saeedi, H., Costello, M. J., Warren, D. \& Brandt, A. Latitudinal and bathymetrical species richness patterns in the NW Pacific and adjacent Arctic Ocean. Sci. Rep. 9, 9303 (2019).

3. Vermeij, G. J., Dietl, G. P. \& Reid, D. G. The trans-Atlantic history of diversity and body size in ecological guilds. Ecology 89, S39-S52 (2008).

4. Moran, A. L. \& Woods, H. A. Why might they be giants? Towards an understanding of polar gigantism. J. Exp. Biol. 215, 1995-2002 (2012).

5. Vermeij, G. J. The evolution of gigantism on temperate seashores. Biol. J. Lin. Soc. 106, 776-793 (2012).

6. Berke, S. K. et al. Beyond Bergmann's rule: size-latitude relationships in marine Bivalvia. Glob. Ecol. Biogeogr. 22, 173-183 (2013).

7. Moretzsohn, F. Cypraeidae: how well-inventoried is the best-known seashell family?. Am. Malacol. Bull. 32, 278-289 (2014).

8. Paulay, G. \& Meyer, C. Dispersal and divergence across the greatest ocean region: do larvae matter?. Integr. Comp. Biol. 46, 269-281 (2006).

9. Meyer, C. P. Molecular systematics of cowries (Gastropoda: Cypraeidae) and diversification patterns in the tropics. Biol. J. Lin. Soc. 79, 401-459 (2003).

10. Meyer, C. P. Toward comprehensiveness: increased molecular sampling within Cypraeidae and its phylogenetic implications. Malacologia 46, 127-156 (2004).

11. Lorenz, F. \& Hubert, A. A Guide to Worldwide Cowries (Conchbooks, Hackenheim, 2000).

12. Cita, M. B. L. Paléocène et l'Eocène de l'Italie du nord. Mémoires du B.R.G.M. 69, 417-429 (1969).

13. Trevisani, E., Bizzotto, B. \& Papazzoni, C. A. The Priabonian platform of the Venetian Prealps in the "flessura pedemontana" (southern Altopiano di Asiago and southern Grappa Massif, Northern Italy): a case history of confused lithostratigraphic nomenclature. Ital. J. Geosci. 128, 739-745 (2009).

14. Bizzotto, B. Prototherium intermedium n. sp. (Sirenia) dell'Eocene Superiore di Possagno e proposta di revisione sistematica del taxon Eotheroides Palmer, 1899. Memorie dell'Istituto di Geologia e Mineralogia dell'Università di Padova 36, 95-116 (1983).

15. Bizzotto, B. Personal communication (2020).

16. Russo, A. Studio monografico sui coralli dell'Eocene di Possagno (Treviso, Italia). Atti e Memorie della Accademia nazionale di Scienze, Lettere ed Arti di Modena 21, 1-87 (1979).

17. Girone, A. \& Nolf, D. Fish otoliths from the Priabonian (Late Eocene) of North Italy and South-East France: their paleobiogeographical significance. Revue de micropaléontologie 52, 195-218 (2009).

18. Fabiani, R. I molluschi eocenici del Monte Postale conservati nel Museo di Geologia della Università di Padova. Atti dell’Accademia scientifica veneto-trentino-istriana 2, 145-158 (1905).

19. Dolin, L. \& Aguerre, O. Les Cypraeidae et les Ovulidae (Mollusca: Caenogastropoda) du Cuisien (Yprésien moyen) du bassin de Paris (nord-ouest de la France). Cossmanniana 18, 3-37 (2016).

20. Pacaud, J.-M. Gisortia (s.str.) coombii (J. de C. Sowerby in Dixon 1850) une espèce emblématique de l'Eocène du bassin de Paris. Fossiles 11, 82-87 (2012).

21. Pacaud, J.-M. Remarques taxonomiques et nomenclaturales sur les mollusques gastéropodes du Paléogène de France et description d'espèces nouvelles. Partie 2. Caenogastropoda (partim). Cossmanniana 21, 101-153 (2019).

22. Trevisani, E. Stratigrafia sequenziale e paleogeografia del margine orientale del Lessini Shelf durante l'Eocene superiore (Prealpi Venete, Province di Vicenza e Treviso). Studi Trentini di Scienze Naturali-Acta Geologica 71(1994), 145-268 (1997).

23. Trevisani, E. The southern Grappa Massif. Annali dell'Università di Ferrara, Scienze della Terra 8(suppl.), 87-93 (2000).

24. Dolin, L. \& Pacaud, J.-M. Les Cypraeoidea et Velutinoidea (Mollusca, Caenogastropoda) du Lutétien inférieur du Vicentin et du Véronais (nord-est de l'Italie). Revue de Paléobiologie 28, 277-314 (2009).

25. Kay, E. A. Evolutionary radiations in the Cypraeidae. In Origin and evolutionary radiation of Mollusca (ed. Taylor, J.) 211-220 (Oxford University Press, Oxford, 1996).

26. Pacaud, J.-M. Sur les spécimens types et figurés des taxons relatifs à Gisortia (s.str.) coombii (Sowerby in Dixon, 1850) (Gastropoda: Cypraeoidea). Cossmanniana 12, 1-45 (2008).

27. Pacaud, J.-M. \& Canevet, J.-M. Considérations sur l’espèce Ovula tuberculosa Duclos, 1825, du Cuisien (Yprésien, Éocène inférieur du Bassin de Paris. Saga Inf. 372, 61-66 (2019). 
28. Darragh, T. A. A revision of the Australian fossil species of Zoila (Gastropoda: Cypraeidae). Mem. Mus. Vic. 68, 1-28 (2011).

29. Darragh, T. A. A revision of the Australian genus Umbilia (Gastropoda: Cypraeidae). Mem. Mus. Vic. 59, 355-392 (2002).

30. Pacaud, J.-M. Loriginal de Gisortia gigantea pterophora Schilder, 1927 (Mollusca, Gastropoda, Cypraeoidea) retrouvé. Cossmanniana 12, 47-53 (2008).

31. Fisher, O. On the Bracklesham Bay Beds of the Isle of Wight Basin. Q. J. Geol. Soc. Lond. 18, 65-94 (1862).

32. Plint, A. G. Facies, environments and sedimentary cycles in the Middle Eocene, Bracklesham Formation of the Hampshire Basin: evidence for global sea-level changes?. Sedimentology 30, 625-653 (1983).

33. Huggett, J. M. \& Gale, A. S. Petrology and palaeoenvironmental significance of glaucony in the Eocene succession at Whitecliff Bay, Hampshire Basin UK. J. Geol. Soc. 154, 897-912 (1997).

34. Pacaud, J.-M. \& Lebrun, P. L'Hippochrenes ampla (Gastéropode éocène) de Gustavus Brander et les débuts de la classification linnéenne des mollusques fossiles par Daniel Solander. Fossiles 17, 28-35 (2016).

35. Dominici, S. \& Zuschin, M. Palaeocommunities, diversity and sea-level change from middle Eocene shell beds of the Paris Basin. J. Geol. Soc. 173, 889. https://doi.org/10.1144/jgs2015-150 (2016).

36. Dominici, S. Paleoecologia e stratigrafia sequenziale dell'Allogruppo di Castigaleu nellarea compresa tra Bacamorta e Val Esera (Eocene Inferiore, Pirenei centro-meridionali, Spagna). Unpublished doctoral thesis, Università di Parma, Italy, 1-94 (1994).

37. Dominici, S. \& Kowalke, T. Depositional dynamics and the record of ecosystem stability: early Eocene faunal gradients in the Pyrenean Foreland Spain. Palaios 22, 268-284 (2007).

38. Farrés, F. \& Staid-Staads, J. L. Cipréidos gigantes del Eoceno catalán. Batalleria 14, 57-66 (2008).

39. Dominici, S. The mollusk fauna of the Monte Postale. Rendiconti della Società Paleontologica Italiana 4, 89-94 (2014).

40. Vescogni, A. et al. Coralgal buildups associated with the Bolca Fossil-Lagerstätten: new evidence from the Ypresian of Monte Postale (NE Italy). Facies 62, 21 (2016).

41. Papazzoni, C. A., Fornaciari, E., Giusberti, L., Vescogni, A. \& Fornaciari, B. Integrating Shallow Benthic and Calcareous Nannofossil Zones: the lower Eocene of the Monte Postale section (northern Italy). Palaios 32, 6-17 (2017).

42. Ludbrook, N. H. Distribution and stratigraphic utility of Cenozoic molluscan faunas in southern Australia. Tohoku Univ. Sci. Rep. 6, 241-261 (1973).

43. Darragh, T. A. A revision of the family Columbariidae (Mollusca: Gastropoda). Proc. R. Soc. Vic. 83, 63-119 (1969).

44. Fitzgerald, E. M. G. A review of the Tertiary fossil Cetacea (Mammalia) localities in Australia. Mem. Mus. Vic. 61, 183-208 (2004).

45. Lorenz, F. Monograph of the living Zoila: A fascinating group of Australian endemic cowries (Mollusca: Prosobranchia: Cypraeidae) (ConchBooks, Hackenheim, 2001).

46. Shepherd, S. \& Edgar, G. Ecology of Australian Temperate Reefs: The Unique South (Cairo Publishing, Cairo, 2013).

47. Petuch, E. J. \& Myers, R. F. Molluscan Communities of the Florida Keys and Adjacent Areas: Their Ecology and Biodiversity (CRS Press, Boca Raton, 2014).

48. Osorio, C., Jara, F. \& Ramirez, M. E. Diet of Cypraea caputdraconis (Mollusca: Gastropoda) as it relates to food availability in Easter Island. Pac. Sci. 47, 34-42 (1993).

49. Wilson, B. R. \& Clarkson, P. Australia's Spectacular Cowries: A Review and Field Study of Two Endemic Genera: Zoila and Umbilia. (Odyssey Publishing, New York, 2004).

50. Richards, Z. et al. Marine biodiversity in temperate western Australia: multi-taxon surveys of Minden and Roe reefs. Diversity 8 , 7 (2016).

51. Passamonti, M. The family Cypraeidae (Gastropoda Cypraeoidea), an unexpected case of neglected animals. Biodivers. J. 6, 449-466 (2015).

52. Zachos, J., Pagani, M., Sloan, L., Thomas, E. \& Billups, K. Trends, rhythms, and aberrations in global climate 65 Ma to present. Science 292, 686-693 (2001).

53. Eldredge, N. \& Gould, S. J. Punctuated equilibria: an alternative to phyletic gradualism. In Models in Paleobiology (ed. Schopf, T. J. M.) 1-250 (Freeman, Cooper \& Co., San Francisco, 1972).

54. Stanley, S. M. A theory of evolution above the species level. Proc. Natl. Acad. Sci. 72, 646-650 (1975).

55. Paulay, G. \& Meyer, C. Diversification in the tropical Pacific: comparisons between marine and terrestrial systems and the importance of founder speciation. Integr. Comp. Biol. 42, 922-934 (2002).

56. McNamara, K. Heterochrony and phylogenetic trends. Paleobiology 8, 130-142 (1982).

57. Renema, W. et al. Hopping hotspots: global shifts in marine biodiversity. Science 321, 654-657 (2008).

58. Cowman, P. F. Historical factors that have shaped the evolution of tropical reef fishes: a review of phylogenies, biogeography, and remaining questions. Front. Genet. 5, 394 (2014).

59. Friedman, M. \& Carnevale, G. The Bolca Lagerstätten: shallow marine life in the Eocene. J. Geol. Soc. 175, 569-579 (2018).

60. Seton, M. et al. Global continental and ocean basin reconstructions since 200 Ma. Earth Sci. Rev. 113, 212-270 (2012).

61. Harzhauser, M., Piller, W. E. \& Steininger, F. F. Circum-Mediterranean Oligo-Miocene biogeographic evolution: the gastropods' point of view. Palaeogeogr. Palaeoclimatol. Palaeoecol. 183, 103-133 (2002).

62. Vermeij, G. J. Shifting sources of productivity in the coastal marine tropics during the Cenozoic era. Proc. R. Soc. Lond. B 278, 2362-2368 (2011).

63. Hunt, G., Wicaksono, S. A., Brown, J. E. \& MacLeod, K. G. Climate-driven body-size trends in the ostracod fauna of the deep Indian Ocean. Palaeontology 53, 1255-1268 (2010).

64. Nürnberg, S., Aberhan, M. \& Krause, R. A. Evolutionary and ecological patterns in body size, shape, and ornamentation in the Jurassic bivalve Chlamys (Chlamys) textoria (Schlotheim, 1820). Foss. Rec. 1, 27-39 (2012).

65. Angilletta, M. J. Jr., Todd, D. S. \& Sears, M. W. Temperature, growth rate, and body size in ectotherms: fitting pieces of a life-history puzzle. Integr. Comp. Biol. 44, 498-509 (2004).

66. Verberk, W. C. E. P. et al. Shrinking body sizes in response to warming: explanations for the temperature-size rule with special emphasis on the role of oxygen. Biol. Rev. https://doi.org/10.1111/brv.12653 (2020).

67. Fortes, R. R. \& Absalão, R. S. Biogeography and connectivity between Western South American and Antarctic Marine molluscs. Oecologia Australis 15, 111-123 (2011).

68. Rypel, A. L. The cold-water connection: Bergmann's rule in North American freshwater fishes. Am. Nat. 183, 147-156 (2014).

69. Audzijonyte, A. et al. Is oxygen limitation in warming waters a valid mechanism to explain decreased body sizes in aquatic ectotherms?. Glob. Change Biol. 28, 64-77 (2019).

70. Goldbogen, J. A. \& Madsen, P. T. The evolution of foraging capacity and gigantism in cetaceans. J. Exp. Biol. 221, jeb166033 (2018).

71. Irie, T., Morimoto, N. \& Fischer, K. Higher calcification costs at lower temperatures do not break the temperature-size rule in an intertidal gastropod with determinate growth. Mar. Biol. 160, 2619-2629 (2013).

72. Irie, T. \& Fischer, K. Ectotherms with a calcareous exoskeleton follow the temperature-size rule: evidence from field survey. Mar. Ecol. Prog. Ser. 385, 33-37 (2009).

73. Bouchet, P. et al. Revised classification, nomenclator and typification of gastropod and monoplacophoran families. Malacologia 61, 1-52 (2017).

74. Hammer Ø. PAST. PAleontological STatistics. Version 3.0. Reference Manual (University of Oslo, 1999-2013).

75. Braga, G. Lassetto tettonico dei dintorni di Possagno (Trevigiano occidentale). Rendiconti dell'Accademia Nazionale dei Lincei 8(48), 451-455 (1970). 


\section{Acknowledgements}

We thank Bruno Bizzotto who collected, prepared and made available the specimen, and professor Iginio Dieni who promoted its study. Stefano Castelli is acknowledged for his valuable help with photographs, and Matteo Dovesi for contributing literature and knowledge on modern cowries. We thank two anonymous reviewers for providing thoughtful and constructive feedback, which was very helpful in improving our manuscript.

\section{Author contributions}

S.D. and M.F. designed the research plan. S.D and L.G. wrote the paper. S.D. performed the analytical work. All authors discussed and commented on the manuscript.

\section{Competing interests}

The authors declare no competing interests.

\section{Additional information}

Supplementary Information The online version contains supplementary material available at https://doi. org/10.1038/s41598-020-78940-9.

Correspondence and requests for materials should be addressed to S.D.

Reprints and permissions information is available at www.nature.com/reprints.

Publisher's note Springer Nature remains neutral with regard to jurisdictional claims in published maps and institutional affiliations.

(c) (i) Open Access This article is licensed under a Creative Commons Attribution 4.0 International

License, which permits use, sharing, adaptation, distribution and reproduction in any medium or format, as long as you give appropriate credit to the original author(s) and the source, provide a link to the Creative Commons licence, and indicate if changes were made. The images or other third party material in this article are included in the article's Creative Commons licence, unless indicated otherwise in a credit line to the material. If material is not included in the article's Creative Commons licence and your intended use is not permitted by statutory regulation or exceeds the permitted use, you will need to obtain permission directly from the copyright holder. To view a copy of this licence, visit http://creativecommons.org/licenses/by/4.0/.

(C) The Author(s) 2020 